\title{
PENGARUH LEVERAGE, MARKET-TO-BOOK RATIO, LIKUIDITAS DAN INTENSITAS ASET TETAP TERHADAP KEPUTUSAN REVALUASI ASET TETAP
}

\author{
Dedrick Gozali \\ Budianto Tedjasuksmana* \\ Universitas Katolik Widya Mandala Surabaya, Jalan Dinoyo 42-44, Surabaya \\ budiano@ukwms.ac.id
}

\author{
A R T I C L E I N F O \\ Article history: \\ Received March 3, 2019 \\ Revised April 14, 2019 \\ Accepted April 21, 2019
}

Key words:

Leverage, Market to book ratio, Liquidity, Fixed assets intensity, Asset revaluation, Fixed asset

\begin{abstract}
A B S T R A C T
Revaluation of fixed assets is one of the reports that must be published by the company in its financial statements. The regulations of their publications are set out in PSAK 16 in which, fixed assets are stated. These information need by investors that must be fulfilled by the companies. Revaluation of asset is considered as relevant information of investors such as on time information, and fit with information that need by investors. The purpose of this research is to analyze and examine leverage, market to book ratio, liquidity, and fixed assets intensity that could be affected to fixed asset revaluation decisions. The sample of this research is manufacturing companies that listed on the BEI in 2015-2016. This research use purposive sampling as sampling method. The regression that used in this research is logistic regression by using quantitative hypothesis. All Financial statement which published is data in this research. The result of this research which variables as, the liquidity, and intensity of fixed assets of the company have no affect on the fixed asset revaluation decisions.
\end{abstract}

A B S T R A K

Revaluasi aset tetap adalah salah satu informasi yang wajib dipublikasikan oleh perusahaan pada laporan keuangannya. Pengaturan dalam publikasinya diatur dalam PSAK 16 tentang Aset Tetap. Perubahan akan kebutuhan informasi oleh investor menjadi suatu keharusan untuk dipenuhi oleh perusahaan. Revaluasi aset dianggap mampu memenuhi informasi yang relevan kepada investor. Penelitian ini bertujuan untuk melakukan analisis dan menguji leverage, market to book ratio, likuiditas, dan intensitas aset tetap terhadap keputusan revaluasi aset tetap.

Penelitian ini menggunakan perusahaan manufaktur yang terdaftar di BEI untuk periode 2015-2016 sebagai sampel yang akan digunakan. Penelitian ini menggunakan purposive sampling dalam melakukan pengambilan sampel. Regresi yang digunakan dalam penelitian ini adalah regresi logistik dengan menggunakan pengujian hipotesis kuantitatif. Data-data yang diperoleh dalam penelitian ini adalah data sekunder yaitu laporan keuangan perusahaan. Pada penelitian ini variabel likuiditas dan intensitas aset tetap perusahaan tidak memiliki pengaruh terhadap keputusan aset tetap perusahaan. Variabel market to book ratio memiliki pengaruh negatif terhadap keputusan revaluasi aset tetap

\section{PENDAHULUAN}

Laporan Keuangan merupakan salah satu sumber informasi yang cukup sering digunakan oleh pihak-pihak yang memiliki kepentingan terhadap keberlangsungan siklus bisnis perusahaan. Pihak-pihak tersebut dibagi menjadi dua kategori besar yaitu pihak internal dan pihak eksternal perusahaan. Kedua pihak tersebut memiliki perbedaan kepentingan. Pihak eksternal perusahaan mengharapkan perusahaan akan menyajikan laporan keuangan yang sesuai dengan keadaan yang sebenarnya. Laporan keuangan dapat digunakan oleh pihak eksternal perusahaan untuk melakukan pengambilan keputusan. Penyajian laporan keuangan yang sesuai dengan standar dapat berdampak pada analisis pihak eksternal yang secara tidak langsung akan berdampak pada pengambilan keputusan baik dalam jangka panjang maupun dalam jangka pendek. IFRS (International Financial Reporting Standart) adalah standar pen- 
yajian laporan keuangan yang saat ini digunakan oleh sebagian besar negara. IFRS dianggap lebih mampu untuk merepresentasikan keadaan perusahaan ke dalam laporan keuangan perusahaan.

Dalam penerapannya, IFRS memberikan kebebasan bagi manajemen untuk memilih metode akuntansi yang paling tepat bagi perusahaan. Kemampuan manajemen dalam memilih sendiri metode akuntansi dapat berdampak pada meningkatnya resiko yang dihadapi oleh pihak eksternal perusahaan. Salah satu hal yang perlu dikaji lebih lanjut dari laporan keuangan perusahaan adalah penggunaan metode revaluasi aset. Penggunaan metode revaluasi aset oleh manajemen akan memberikan dampak pada beberapa nilai yang diungkapkan dalam laporan keuangan. Perubahan nilai yang terjadi dapat berakibat pada perubahan beberapa rasio keuangan perusahaan.

Perubahan nilai pada rasio keuangan perusahaan dapat memberikan dampak terhadap keputusan yang akan diambil oleh pihak eksternal perusahaan. Salah satu rasio keuangan yang digunakan adalah leverage. Pada umumnya, kreditor akan menggunakan rasio leverage untuk mengukur tingkat resiko gagal bayar pada perusahaan. Selain menggunakan leverage, pada umumnya kreditor juga menggunakan rasio likuiditas untuk mengukur kemampuan perusahaan dalam mengelola resiko jangka pendek yang dihadapi oleh perusahaan. Dalam hal ini, perusahaan dapat meningkatkan kredibilitasnya dihadapan kreditor dengan memberikan jaminan atas hutangnya dengan aset perusahaan. Andison (2015) menjelaskan bahwa salah satu faktor dalam penentuan revaluasi aset tetap adalah leverage.

Leverage sendiri merupakan rasio yang sering digunakan untuk menggambarkan resiko perusahaan di masa depan. Leverage dianggap mampu menggambarkan kemampuan perusahaan dalam mendanai asetnya di masa sekarang. Salah satu metode yang umumnya digunakan oleh pihak manajemen perusahaan untuk menurunkan tingkat rasio leverage perusahaan adalah dengan menaikan ekuitas perusahaan. Sebagai upaya untuk menaikan ekuitas perusahaan tersebut adalah dengan menaikan nilai aset perusahaan melalui proses revaluasi.

Salah satu rasio yang berfokus pada ekuitas adalah market to book ratio. Rasio ini digunakan oleh investor untuk mengukur tingkat pertumbuhan perusahaan. Rasio ini memberikan asumsi kepada investor sejauh mana perusahaan diakui oleh banyak investor lainnya berdasarkan harga pasar perusahaan. Nilai market to book ratio yang terlalu tinggi dapat mengakibatkan munculnya indikasi adanya aset yang dinilai undervalued (Andison, 2015). Aset yang undervalued dapat berakibat pada munculnya asumsi investor mengenai kinerja manajemen perusahaan dalam mengelola aset-aset perusahaan. Hal tersebut dikarenakan investor dapat berasumsi bahwa depresiasi aset perusahaan lebih cepat daripada yang seharusnya. Depresiasi aset yang lebih cepat tersebut berpengaruh pada laporan beban penyusutan perusahaan pada periode-periode sebelumnya. Oleh karena itu, manajemen cenderung akan melaporkan aset perusahaan berdasarkan nilai wajar atau nilai perusahaan.

Tingkat kemampuan perusahaan dalam melakukan pembayaran hutang jangka pendek kepada kreditor menjadi salah satu hal yang dipertimbangkan oleh pihak eksternal perusahaan. Kemampuan perusahaan dalam melakukan pembayaran tersebut dapat di representasikan melalui rasio likuiditas. Rasio likuiditas yang jauh diatas tingkat normal dapat menggambarkan bahwa manajemen kurang baik dalam mengelola aset atau bahkan dapat menjadi indikasi bahwa perusahaan berada dalam proses mendekati likuidasi.

Dalam teori keagenan dijelaskan bahwa terdapat asimetri informasi antara stakeholder dengan manajemen perusahaan. Salah satu pengukuran asimetri informasi adalah dengan menggunakan intensitas aset tetap perusahaan, Seng dan Su (2010). Selain untuk mengukur asimetri informasi, penggunaan intensitas aset tetap juga dapat digunakan untuk mengukur kinerja manajemen dalam mengelola hutang yang ada. Hal tersebut dikarenakan dalam pembiayaan aset, perusahaan menggunakan salah satu struktur pendanaan yaitu hutang pada kreditor.

Pada umumnya aset tetap sebuah perusahaan merupakan bagian terbesar dalam proporsi total aset perusahaan. Dalam pengukurannya berdasarkan standar sebelum IFRS, aset yang diperoleh akan dicatat berdasarkan biaya perolehan ditambahkan dengan biaya-biaya lainnya yang bertujuan untuk mendapatkan aset tersebut. Namun seiring dengan perubahan ekonomi yang terjadi, beberapa aset yang akan dijual oleh perusahaan mengalami perbedaan dengan nilai buku yang tercatat. Selisih nilai yang terjadi menjadi dasar atas munculnya asumsi bahwa standar pelaporan keuangan tidak dapat merepresentasikan keadaan ekonomi perusahaan dengan tepat. Dalam menanggapi isu tersebut, IFRS mengeluarkan metode baru yaitu metode revaluasi aset. Nilai atas sebuah aset dapat dinilai kembali dan disesuaikan dengan 
harga yang beredar. Metode tersebut dipublikasikan dengan tujuan untuk menjaga relevansi nilai dari suatu aset.

Di Indonesia, PSAK 16 yang mengatur mengenai aset tetap, penilaian setelah pengukuran awal dibagi menjadi dua pilihan metode yaitu metode biaya dan metode revaluasi. Metode biaya dihitung berdasarkan harga perolehan dari aset tersebut yang kemudian disusutkan . Sedangkan untuk metode revaluasi, nilai aset akan dinilai kembali berdasarkan nilai pasar atas aset tersebut. Kedua metode tersebut menyebabkan terjadinya distorsi akuntansi. Nilai aset yang dinilai dengan menggunakan metode biaya dianggap memiliki kehandalan dalam penilaiannya. Nilai aset yang dinilai dengan menggunakan metode revaluasi dianggap memiliki relevansi dengan nilai saat ini.

Kemampuan manajemen untuk memilih sendiri metode yang akan digunakan serta distorsi akuntansi yang terjadi antara penerapan metode biaya dengan metode revaluasi aset menjadi dasar dilakukannya penelitian ini. Penelitian ini dilakukan dengan menggunakan perusahaan manufaktur sebagai populasi penelitian. Selanjutnya, perusahaan manufaktur yang akan menjadi sampel penelitian ini adalah perusahaan manufaktur pada periode 2015-2016. Pada 18 November 2015, DSAK menerbitkan penyesuaian tahunan. Salah satu standar yang disesuaikan dalam publikasi tersebut adalah PSAK 16 yang mengatur aset tetap. Hal yang disesuaikan dalam publikasi tersebut adalah jika entitas melakukan model revaluasi, maka nilai tercatat aset akan disajikan kembali sesuai dengan jumlah revaluasiannya. Hal ini diasumsikan merupakan suatu kesempatan yang diberikan kepada manajemen untuk mengatur strategi penyusunan laporan keuangan yang sesuai dengan keadaan perusahaan. PSAK 16 sendiri berlaku efektif sejak Januari 2016 namun diperbolehkan untuk melakukan penerapan dini. Dari penjelasanpenjelasan yang telah diuraikan sebelumnya, maka peneliti memberikan judul atas penelitian ini yaitu, pengaruh leverage, market to book ratio, likuiditas, dan intensitas aset tetap terhadap keputusan revaluasi aset tetap.

Berdasarkan penjelasan yang telah diuraikan pada bagian latar belakang maka dapat dirumuskan permasalahan dalam penelitian sebagai berikut: Apakah terdapat pengaruh leverage, market-tobook ratio, likuiditas, dan intensitas aset tetap terhadap Keputusan Revaluasi Aset Tetap, dengan tujuan penelitian untuk menguji dan menganalisis pengaruh leverage, market-to-book ratio, likuiditas, dan intensitas aset tetap terhadap Keputusan Revaluasi Aset Tetap. Penelitian ini diharapkan dapat memberikan penjelasan informasi mengenai keputusan manajemen dalam pengambilan keputusan revaluasi aset tetap perusahaan.

\section{KAJIAN LITERATUR DAN PENGEMBANGAN HIPOTESIS}

Teori Keagenan

Teori keagenan diperkenalkan pertama kali oleh Jensen dan Meckling pada tahun 1976. Teori ini mendeskrpsikan bagaimana hubungan yang terjadi antara agensi (perusahaan atau manajemen) dengan prinsipal (shareholder). Teori ini menjelaskan bahwa adanya asimetri informasi yang terjadi antara agensi dengan prinsipal dimana asimetri informasi yang terjadi tersebut tidak dapat dihilangkan sepenuhnya sebagai akibat dari adanya perbedaan kepentingan satu sama lain.

Perbedaan kepentingan yang terjadi di perusahaan saat ini sering dikatikan dengan laporan keuangan perusahaan. Manajemen memiliki tanggung jawab untuk menyusun laporan keuangan yang sesuai dengan keadaan seharusnya agar dapat memberikan informasi kepada shareholder untuk melakukan keputusan-keputusan penting yang salah satunya adalah investasi. Selanjutnya selain tanggung jawab yang dimiliki oleh manajemen, manajemen juga memiliki hak untuk mendapatkan kemakmuran atas kinerjanya yang telah diberikan kepada perusahaan. Pemberian kemakmuran ini sering kali didasari atas kinerja yang telah dihasilkan oleh manajemen. Pemberian kemakmuran yang didasari oleh sesuatu inilah yang mengakibatkan manajemen cenderung untuk menyusun laporan keuangan yang dapat memberikan kemakmuran bagi pribadi.

\section{Teori Akuntansi Positif}

Dalam perlakuannya, akuntansi memiliki dua pendekatan secara umum yaitu teori akuntansi normatif dan teori akuntansi positif. Teori akuntansi normatif adalah teori akuntansi yang bertujuan untuk menggambarkan interaksi antar variabel yang terdapat dalam ilmu akuntansi. Sedangkan teori akuntansi positif adalah teori akuntansi yang menjelaskan proses, pemahaman, serta penggunaan kebijakan akuntansi yang paling sesuai dengan kondisi tertentu dimasa depan. Pada dasarnya, teori ini bertujuan untuk menjelaskan penggunaan teori-teori akuntansi.

Dalam teori akuntansi positif, terdapat salah satu hipotesis yang mengarah pada insentif mana- 
jemen yaitu hipotesis bonus. Hipotesis ini menjelaskan bahwa apabila pengukuran kinerja manajemen berdasarkan laba perusahaan, maka manajemen memiliki kecenderungan untuk menggunakan dan melaporkan laba mereka dengan menggunakan metode-metode akuntansi yang dapat meningkatkan pelaporan labanya. Pelaporan yang didasari hal seperti itu akan mengakibatkan penurunan laba dimasa mendatang sebagai akibat dari penggunaan metode akrual basis.

Selanjutnya, dalam teori akuntansi positif dibahas juga hipotesis mengenai kontrak hutang atau biasa disebut debt convenant. Hipotesis ini menjelaskan bahwa penyusunan laporan keuangan perusahaan yang tidak sesuai dengan standart yang ada akan berakibat pada munculnya asumsi bahwa manajemen melakukan pemilihan metode yang mengakibatkan perubahan laba yang dilaporkan dari periode masa depan ke periode masa kini.

\section{Revaluasi Aset Tetap}

Berdasarkan International Accounting Standard Board (2003), aset tetap adalah aset yang digunakan untuk melakukan proses produksi barang atau jasa ataupun juga dapat disewakan kepada pihak lain selain itu, aset tersebut juga dapat digunakan lebih dari satu periode. Sementara itu, untuk penilaian aset tetap tersebut pada pengakuan awalnya dicatat sebesar biaya yang dikeluarkan untuk mendapatkan aset tersebut.

Dalam PSAK 16 tahun 2016 mengenai aset tetap, penggunaan metode revaluasi aset setelah pengakuan awal sendiri terdiri dari dua model yaitu model biaya dan model revaluasi. Model biaya mengakui nilai suatu aset yang telah diakui sebelumnya dikurangi dengan akumulasi penyusutan dan impairment loss. Penerapan perlakuan dalam model ini sama dengan perlakuan dengan standart yang sudah ada sebelumnya. Model biaya ini masih banyak digunakan oleh banyak perusahaan karena dianggap memiliki nilai handal yang lebih dan dianggap lebih cocok dengan karakter perusahaan.

Model revaluasi menerapkan salah satu konsep akuntansi yaitu relevansi, dimana nilai atas suatu aset diakui menjadi nilai yang berlaku saat ini. Dalam perhitungannya, suatu aset akan dinilai menjadi nilai wajar atas suatu aset pada tanggal dimana aset tersebut ingin direvaluasi, setelahnya akan dikurangi penyusutan dan impairment loss dari aset tersebut. Penggunaan metode ini haruslah dilakukan secara berkala untuk tetap menjaga peru- bahan nilai yang mungkin dapat menjadi cukup signifikan. Dalam penerapan model revaluasi ini, terdapat dua jenis revaluasi yang dapat dipilih oleh manajemen yaitu model upward revaluation, aset yang akan direvaluasi mengalami kenaikan atas nilai tercatat; model downward revaluation, aset yang direvaluasi mengalami penurunan nilai hal ini dikarenakan nilai pasar dari aset tersebut berada dibawah nilai tercatatnya.

\section{Leverage}

Leverage merupakan salah satu rasio keuangan yang paling umum digunakan oleh banyak kalangan pemegang kepentingan. Rasio ini digunakan untuk mengukur seberapa besar pembiayaan aset oleh hutang di sebuah perusahaan. Selain itu, leverage juga dapat digunakan untuk melihat struktur pendanaan perusahaan. Army (2013) menjelaskan bahwa perusahaan yang menggunakan struktur hutang dalam membiayai asetnya dinilai cenderung memiliki resiko dimasa depan. Resiko tersebut muncul karena perusahaan dihadapkan untuk membayar beban bunga atas hutangnya. Rasio leverage dapat digunakan sebagai pertimbangan oleh kreditor untuk memberikan pinjamannya kepada perusahaan.

Penelitian di Swiss yang dilakukan oleh Missonier-Piera (2007) menjelaskan bahwa adanya hubungan positif antara rasio leverage dengan revaluasi aset. Hal tersebut didukung dengan asumsi bahwa perusahaan dengan leverage yang tinggi akan menggunakan metode revaluasi untuk menurunkan biaya hutang mereka. Penurunan biaya tersebut terjadi karena adanya pembebanan pada awal periode revaluasi sebagai akibat dari biaya atas jasa penilaian kembali serta pembayaran pajak diawal tahun penggunaan metode revaluasi. Selanjutnya, Sherlita dan Sari (2015) menjelaskan bahwa perusahaan yang memberikan jaminan aset perusahaan atas hutangnya akan memperoleh beban hutang yang lebih kecil dibandingkan dengan hutang tanpa jaminan dari perusahaan. Sama halnya dengan penelitian yang dilakukan oleh Missonier-Piera (2007), Seng dan Su (2010) juga melakukan penelitian mengenai faktor-faktor yang mempengaruhi revaluasi aset. Seng dan Su (2010) berpendapat bahwa perusahaan yang memiliki tingkat leverage yang tinggi memiliki kecenderungan melakukan revaluasi aset.

\section{Market-to-book ratio}

Market to book ratio merupakan rasio yang dinilai dengan membandingkan nilai pasar dari suatu perusahaan dengan nilai tercatatnya. Rasio 
ini merupakan salah satu alat untuk mengukur sejauh mana perusahaan telah bertumbuh dari periode ke periode. Market-to-book ratio yang tinggi berdampak pada aset undervalued dimana hal tersebut dapat memperpengaruhi kebijakan yang akan diambil oleh perusahaan untuk melakukan revaluasi aset tetap. Ketika nilai pasar perusahaan jauh berada dibawah nilai buku perusahaan, manajemen cenderung akan melakukan revaluasi dengan harapan akan memberikan investor mengenai kemampuan perusahaan dalam melakukan operasional lanjutan yang akan dilaporkan manajemen.

Pertumbuhan laba yang positif dari tahun ke tahun akan memberikan investor gambaran bahwa perusahaan mengalami peningkatan dalam proses bisnisnya. Pertumbuhan tersebut dapat mempengaruhi keputusan investor untuk menanamkan sahamnya di perusahaan tersebut. Semakin banyak investor yang tertarik dengan proses bisnis perusahaan, akan semakin mempengaruhi nilai dari perusahaan tersebut. Hasil akhir dari nilai perusahaan yang meningkat adalah dengan meningkatnya ekspetasi investor yang melebihi nilai buku ekuitas tercatat oleh perusahaan.

\section{$\underline{\text { Likuiditas }}$}

Selain menggunakan rasio leverage, pihak stakeholder pada umumnya juga menggunakan rasio likuiditas dalam memeriksa keadaan keuangan perusahaan. Likuiditas merupakan rasio yang dapat digunakan untuk melakukan analisis sejauh mana kemampuan aset perusahaan untuk melunasi hutang jangka pendek perusahaan. Tay (2009) menjelaskan bahwa perusahaan akan memiliki kecenderungan untuk melakukan revaluasi aset tetap apabila memiliki tingkat rasio likuiditas yang tinggi. Pada penelitian yang dilakukan oleh Tay (2009), pendapat tersebut didasari dengan adanya asumsi bahwa perusahaan dengan tingkat likuiditas yang tinggi lebih leluasa untuk melakukan pengambilan kebijakan. Perusahaan dengan tingkat likuiditas yang tinggi memiliki kecenderungan untuk mempunyai kemampuan meminjam dana kepada kreditor dengan lebih mudah dibandingkan dengan perusahaan yang memiliki tingkat likuiditas rendah.

Selain untuk mengukur kemampuan pembayaran hutang, rasio likuiditas juga dapat digunakan sebagai salah satu pengukur atas kinerja manajemen perusahaan dalam mengelola resiko perusahaan. Resiko yang dikelola oleh perusahaan tersebut adalah resiko atas hutang beban bunga perusahaan dalam jangka pendek. Struktur pendanaan perusahaan yang didasari dengan hutang akan menimbulkan beban bunga bagi perusahaan. Diperlukan pengelolaan atas pinjaman dana tersebut agar dapat memberikan nilai yang efektif bagi perusahaan. Kemampuan pengelolaan tersebut dapat menjadi indikator atas kinerja manajemen dalam mengelola resiko perusahaan. Investor tentu mengharapkan tingkat pengembalian investasi mereka sesuai dengan ekspetasi mereka terhadap perusahaan. Kreditor sebagai salah satu pihak eksternal, mengharapkan bahwa perusahaan dapat membayar pinjaman yang mereka berikan sesuai dengan nilai yang telah disepakati dalam waktu yang telah disetujui.

\section{Intensitas Aset Tetap}

Rasio intensitas aset tetap dapat digunakan sebagai salah satu cara untuk melihat tingkat proporsi dari aset tetap yang dimiliki terhadap total aset perusahaan. Intensitas aset tetap dapat membantu pihak stakeholder untuk melihat sejauh mana kemampuan manajer dalam mengelola aset-aset perusahaan. Perusahaan yang memiliki proporsi aset tetap lebih besar daripada aset lancar kurang disenangi oleh kreditor. Hal tersebut dikarenakan adanya asumsi bahwa adanya resiko atas kemampuan perusahaan dalam membayar hutangnya kepada kreditor. Selanjutnya, investor memiliki kecenderungan untuk fokus pada bagian aset tetap perusahaan. Hal ini dikarenakan pada umumnya, perusahaan memiliki nilai aset tetap yang lebih besar daripada nilai aset lancarnya. Nilai tersebut dirasa dapat memberikan pengaruh terhadap ekuitas perusahaan secara signifikan. Peningkatan nilai dari aset tetap dapat menjadi sinyal bagi investor bahwa kinerja manajemen mengalami peningkatan.

Andison (2015) menemukan bahwa intensitas aset tetap yang besar akan mempengaruhi keputusan manajemen dalam melakukan revaluasi aset tetap perusahaan. Nilai aset tetap dapat menjadi ekspetasi bagi pihak eksternal dalam menilai kas yang dapat diterima saat melakukan penjualan aset. Nilai kas tersebut merupakan bagian dari pengukuran resiko yang dihadapi oleh pihak eksternal.

\section{Pengaruh Leverage terhadap Keputusan Revaluasi Aset Tetap}

Rasio leverage menjadi salah satu alat ukur yang sering digunakan oleh kreditor. Hal tersebut menjadi salah satu faktor yang menyebabkan manajemen menjadi fokus dalam perhitungan rasio 
keuangan perusahaan. Revaluasi aset dapat membantu manajemen dalam memanfaatkan metode akuntansi yang dapat mempengaruhi perhitungan rasio keuangan perusahaan.

Andison (2015) menemukan bahwa leverage memiliki pengaruh positif terhadap keputusan revaluasi aset perusahaan. Dalam penelitiannya, Andison menjelaskan bahwa tingkat leverage yang tinggi menggambarkan bahwa perusahaan dalam membiayai investasi asetnya adalah berdasarkan hutang daripada modal sendiri. Manihuruk dan Farahmita (2014) menemukan hal yang sama yaitu leverage memiliki pengaruh positif terhadap keputusan revaluasi aset. Hal tersebut dikarenakan perusahaan akan berusaha memberikan kelayakan dihadapan kreditor.

H1 : Leverage memiliki pengaruh positif terhadap keputusan revaluasi aset.

\section{Pengaruh Market to Book Ratio terhadap Keputusan Revaluasi Aset Tetap}

Market to book ratio merupakan salah satu rasio yang dapat digunakan untuk mengukur tingkat pertumbuhan perusahaan dari sisi investor. Selanjutnya, penghitungan dari rasio ini didapatkan dari membandingkan nilai buku ekuitas dengan nilai pasar dari perusahaan. Pinjaman dana yang berasal dari kreditor tidak sepenuhnya dapat dijamin dengan aset perusahaan (Andison, 2015).

Hasil penelitian yang dilakukan oleh Tay (2009) menemukan market to book ratio memiliki pengaruh negatif terhadap keputusan untuk revaluasi aset tetap. Hal tersebut didasari adanya syaratsyarat yang harus dipenuhi oleh perusahaan untuk sesuai dengan kontrak atas pinjaman yang telah disetujui oleh perusahaan dan kreditor. Perusahaan akan mendapatkan sanksi yang sesuai dengan persetujuan ketika tidak memenuhi persyaratan yang telah di sepakati.

H2 : Market to Book Ratio memiliki pengaruh negatif terhadap keputusan revaluasi aset.

Pengaruh Likuiditas terhadap Keputusan Revaluasi Aset Tetap

Likuiditas merupakan rasio yang cukup sering digunakan untuk mengukur tingkat kecepatan pembayaran hutang perusahaan berdasarkan aset lancar perusahaan selain persediaan. Rasio ini membandingkan antara aset lancar perusahaan dengan hutang lancar perusahaan. Perbandingan ini dilakukan dikarenakan adanya asumsi mengenai perusahaan memiliki keharusan untuk fokus terhadap beban hutang jangka pendek, sementara itu perusahaan memerlukan aset yang cepat untuk melunasi beban hutang tersebut.

Tay (2009) menemukan adanya hubungan positif antara likuiditas dengan keputusan revaluasi aset tetap. Harga pasar atas aset dinilai dapat memberikan prediksi yang lebih tepat bagi stakeholder mengenai kas yang akan mereka dapatkan dari penjualan aset tetap tersebut. Nilai atas kas tersebut dianggap mampu membantu stakeholder mengenai tingkat resiko yang mereka hadapi.

H3: Likuiditas memiliki pengaruh positif terhadap keputusan revaluasi aset.

\section{Pengaruh Intensitas Aset Tetap terhadap Keputusan Revaluasi Aset Tetap}

Intensitas aset tetap merupakan proporsi aset tetap perusahaan dalam total aset perusahaan. Perhitungan tersebut dapat digunakan untuk mengukur asimetri informasi, Seng dan Su (2010). Asimetri informasi tersebut terjadi antara pihak stakeholder dengan manajemen perusahaan. Untuk mengukur sejauh mana asimetri yang terjadi antara stakeholder dengan manajemen perusahaan maka dapat digunakan intensitas aset informasi.

Latifa dan Haridhi (2016) menemukan bahwa terdapat hubungan positif antara intensitas aset tetap terhadap keputusan revaluasi aset tetap. Manihuruk dan Farahmita (2015) juga menemukan bahwa intensitas aset tetap memiliki hubungan positif terhadap keputusan revaluasi aset tetap perusahaan. Hal tersebut didasari bahwa penggunaan metode revaluasi aset tetap dapat mempengaruhi total aset perusahaan secara signifikan. Pengaruh tersebut terjadi karena nilai aset tetap yang direvaluasi memiliki nilai yang besar.

H4: Intensitas Aset Tetap memiliki pengaruh positif terhadap keputusan revaluasi aset.

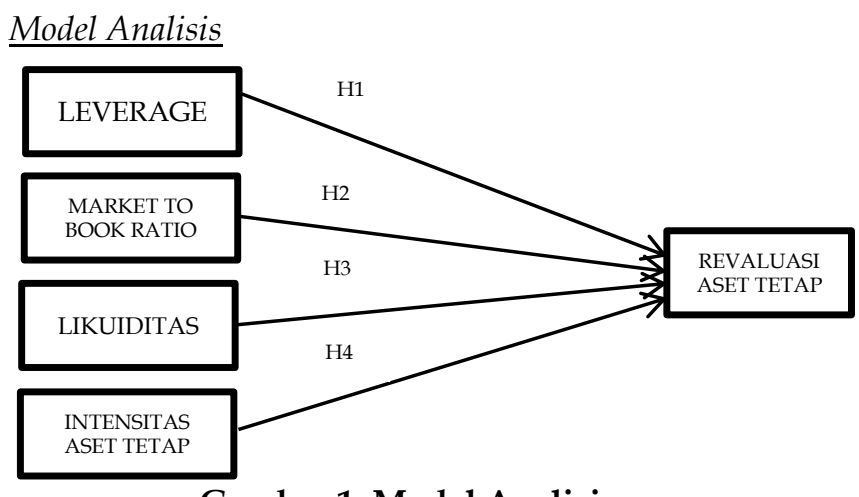

Gambar 1. Model Analisis

\section{METODE PENELITIAN}

\section{Populasi dan Sampel}

Populasi dalam penelitian ini adalah perusahaan manufaktur yang terdaftar di BEI. Sampel 
yang diambil dari populasi tersebut diambil dengan menggunakan metode purposive sampling dengan kriteria sebagai berikut :

1. Perusahaan manufaktur yang menggunakan mata uang rupiah pada laporan keuangan.

2. Perusahaan manufaktur yang terdaftar di BEI pada periode 2015-2016.

3. Perusahaan yang memberikan informasi yang dibutuhkan untuk penelitian.

Tabel 1. Seleksi Sampel

\begin{tabular}{|c|c|}
\hline Keterangan & $\begin{array}{c}\text { Jumlah } \\
\text { Perusahaan }\end{array}$ \\
\hline $\begin{array}{l}\text { Populasi: Perusahaan } \\
\text { manufaktur yang terdaftar di } \\
\text { BEI }\end{array}$ & 143 \\
\hline $\begin{array}{lr}\text { Perusahaan yang } & \text { tidak } \\
\text { memenuhi kriteria: } & \\
\text { 1. } & \text { Perusahaan } \\
\text { menggunakan yang } & \text { mata } \\
\text { uang asing dalam } & \text { pelaporan keuangannya }\end{array}$ & 25 \\
\hline $\begin{array}{l}\text { 2. Perusahaan yang tidak } \\
\text { memberikan informasi } \\
\text { yang diperlukan dalam } \\
\text { penelitian ini }\end{array}$ & 16 \\
\hline Total & 102 \\
\hline
\end{tabular}

Sumber: Data diolah

\section{Definisi Operasional dan Pengukuran Variabel}

1. Keputusan revaluasi aset tetap (RAT)

Revaluasi aset adalah penialaian kembali suatu aset berdasarkan nilai pasar yang berla$\mathrm{ku}$ di periode pengakuan revaluasi, Brown, Izanand dan Loh (1992). Pada penelitian ini, variabel RAT akan diukur dengan menggunakan variabel dummy. Perusahaan yang melakukan revaluasi akan diberikan nilai 1 , dan nilai 0 untuk perusahaan yang tidak melakukan revaluasi.

2. Leverage

Leverage merupakan salah satu rasio yang dapat digunakan untuk mengukur struktur pendanaan perusahaan. Pada penelitian ini, rasio leverage akan diukur dengan perhitungan sebagai berikut:

$$
L V R=\frac{\text { Total hutang }}{\text { Total ekuitas }}
$$

3. Market to book ratio (MTB)

Market to book ratio digunakan untuk men- gukur pertumbuhan perusahaan. Rasio ini digunakan untuk melihat seberapa besar nilai ekspetasi pemegang saham dibandingkan dengan nilai ekuitas atau nilai tercatat perusahaan. Pada penelitian ini, MTB akan dinilai dengan rumus sebagai berikut:

4. Likuiditas (LDT)

$$
\text { MTB }=\frac{\text { Market value }+ \text { Total hutang }}{\text { Total ekuitas }}
$$

Rasio likuiditas dapat digunakan untuk mengukur tingkat kecepatan pemenuhan tanggung jawab perusahaan atas hutang jangka pendek perusahaan berdasarkan aset lancar perusahaan. Pada penelitian ini, LDT akan dinilai dengan rumus sebagai berikut:

$$
L D T=\frac{(\text { Aset lancar }- \text { Persediaan })}{\text { Hutang lancar }}
$$

5. Intensitas Aset Tetap (IAT)

Perhitungan intensitas aset tetap dapat digunakan untuk mengukur asimetri informasi yang terjadi. Asimetri tersebut berupa ketidak mampuan pihak eksternal untuk mengetahui karakteristik internal perusahaan secara keseluruhan. Dalam penelitian ini, IAT akan dinilai dengan rumus sebagai berikut:

$$
I A T=\frac{\text { Aset tetap }}{\text { Total aset }}
$$

\section{$\underline{\text { Teknik Analisis Data }}$}

Dalam penelitian ini, regresi yang digunakan adalah regresi logistik. tahapan analisis yang digunakan adalah sebagai berikut:

$$
\text { 1. Persamaan Regresi }
$$

$$
\begin{aligned}
\frac{P(R A T)}{1-P(R A T)}=\alpha & +\beta 1 . L V R+\beta 2 . M T B+\beta 1 . L T D \\
& +\beta 1 . I A T+\varepsilon
\end{aligned}
$$

Keterangan:

RAT : Tingkat kemungkinan perusahaan menggunakan kebijakan revaluasi aset tetap

LVR : Rasio leverage perusahaan

MTB : Rasio market to book ratio perus-

ahaan

a : Konstanta

LDT : Likuiditas

IAT : Intensitas Aset Tetap

$\varepsilon \quad:$ Nilai error

2. Statistik Deskriptif

Tahapan ini digunakan untuk melihat nilai mean, standart deviasi, dan nilai maksimal dan minimal. Tahapan ini digunakan untuk melihat 
nilai-nilai dari olahan data yang dilakukan secara umum oleh statistic (Ghozali, 2016).

3. Uji Model Fit

Tahapan ini digunakan untuk menilai kecocokan antara variabel yang dipilih dan diinterpretasikan melalui regresi yang telah dibuat sebelumnya. Dalam pengujian ini, digunakan nilai dari fungsi Likelikhood L atau -2LogL (Ghozali, 2016). Dalam uji model fit ini, muncul dua hipotesis dalam pengambilan kesimpulan dari nilai -2Log L yaitu :

H0 : Persamaan regresi cocok dengan data yang ada

Ha : Persamaan regresi tidak cocok dengan data yang ada.

4. Uji Hosmer and Lemeshow

Tahapan ini digunakan untuk menguji ketepatan data yang digunakan terhadap persamaan regresi yang telah disusun. Kesimpulan dari pengujian ini adalah berdasarkan hipotesis yang telah disusun diatas yaitu H0. Nilai statistik dari Hosmer and Lemeshow lebih dari 0,05 mengakibatkan pengambilan kesimpulan yaitu hipotesis H0 memiliki model yang cocok dengan data yang ada. Selanjutnya, Nilai statistik dari Hosmer and Lemeshow kurang dari 0,05 mengakibatkan pengambilan kesimpulan lainnya yaitu hipotesis $\mathrm{H0}$ memiliki model yang tidak cocok dengan data yang ada (Ghozali, 2016).

5. Uji Koefisien Determinasi

Pada tahapan ini, data-data yang diperoleh akan diuji sejauh mana variabel dependen dapat dijelaskan oleh variabel independen (Ghozali, 2016). Nilai yang keluar dalam tabel Nagelkerke $\mathrm{R}$ Square akan dikalikan dengan seratus persen untuk memperoleh tingkat kemampuan variabel independen dalam menjelaskan variabel dependen.

6. Pengujian Hipotesis

Penilaian hipotesis pada penelitian ini digunakan dengan menggunakan regresi logistik. Regresi logistik sendiri digunakan untuk mengukur probabilitas atau kemungkinan terjadinya suatu kejadian didasari oleh data pada kurva logistik (Ghozali, 2016). Pengambilan keputusan pada pengujian hipotesis ini berdasarkan hal-hal sebagai berikut:

a. Perumusan Hipotesis

H0 : Variabel Independen (Leverage, Market to Book Ratio,Likuiditas, dan Intensitas Aset Tetap) tidak memiliki pengaruh terhadap variabel Dependen (Keputusan Revaluasi Aset Tetap)
H1 : Variabel Independen (Leverage, Market to Book Ratio,Likuiditas, dan Intensitas Aset Tetap) memiliki pengaruh terhadap variabel Dependen (Keputusan Revaluasi Aset Tetap).

b. Pengambilan Kesimpulan,

(1) Apabila nilai regresi > 0,05 maka $\mathrm{HO}$ diterima, dan $\mathrm{H} 1$ ditolak.

(2) Apabila nilai regresi < 0,05 maka H0 ditolak, dan $\mathrm{H} 1$ diterima.

\section{HASIL DAN PEMBAHASAN}

Statistik deskriptif

Hasil statistik deskriptif variabel penelitian dapat dilihat pada tabel 2 dan 3 di bawah ini:

Tabel 2. Hasil Statistik Deskriptif Variabel

\begin{tabular}{|c|c|c|c|c|c|}
\hline Var & $\mathrm{N}$ & $\begin{array}{c}\text { Std. Devia- } \\
\text { tion }\end{array}$ & Mean & Max & Min \\
\hline Lvr & 204 & 1.274 & 0.976 & 7.372 & -5.023 \\
\hline Mtb & 204 & 7.294 & 3.673 & 65.491 & -6.196 \\
\hline Lkd & 204 & 2.225 & 1.702 & 17.368 & -3.520 \\
\hline Iat & 204 & 5.042 & 0.796 & 71.865 & 0.032 \\
\hline
\end{tabular}

Tabel 3. Hasil Statistik Deskriptif Variabel RAT

\begin{tabular}{|l|c|c|}
\hline \multicolumn{1}{|c|}{ Keterangan } & Frekruensi & $\begin{array}{c}\text { Persentase } \\
(\%)\end{array}$ \\
\hline $\begin{array}{l}\text { Perusahaan yang } \\
\text { melakukan revaluasi } \\
\text { aset tetap }\end{array}$ & 52 & 25,49 \\
\hline $\begin{array}{l}\text { Perusahaan yang } \\
\text { tidak melakukan re- } \\
\text { valuasi aset tetap }\end{array}$ & 152 & 74,51 \\
\hline Jumlah & 204 & 100 \\
\hline
\end{tabular}

Berdasarkan hasil dari penelitian yang ditunjukan pada tabel 3 terdapat $25,49 \%$ perusahaan pada periode 2015-2016 melakukan revaluasi aset tetap sedangkan sisanya tidak melakukan revaluasi aset tetap. Hal ini menunjukan bahwa sebagian besar perusahaan manufaktur yang terdaftar di bei pada periode tersebut memiliki kecenderungan untuk tidak melakukan revaluasi aset tetap perusahaan.

\section{Analisis data}

1. Uji model fit

Hasil uji dengan menggunakan uji model fit dapat dilihat dari nilai yang ada pada kolom $2 \log$ likelihood. Tujuan dari penggunaan metode ini pada penelitian adalah untuk mencocokan apakah data yang digunakan dalam penelitian dapat digunakan dalam model regresi yang 
sudah ditetapkan sebelumnya. Nilai -2log likehood sebelum dimasukan variabel independen adalah 231,604. Nilai dari $-2 \log$ likelihood mengalami penurunan sebesar 19,554. Penurunan nilai pada tabel -2log likelihood menunjukan kecocokan ketika empat variabel independen dimasukan kedalam model regresi tersebut. Kecocokan data dengan model regresi yang ada menunjukan bahwa data yang digunakan fit dengan model regresi yang dihipotesiskan.

2. Uji hosmer and lemeshow

Hasil dari pengujian hosmer and lemeshow menunjukkan bahwa nilai signifikansi adalah sebesar 0,681 atau $68,1 \%$ yang berarti model regresi dinilai dapat meprediksi nilai dari olahan datanya. Nilai signifikansi pada hasil uji tersebut berada di atas 0,05 atau 5\%. Hal tersebut menjelaskan bahwa model regresi layak untuk digunakan.

3. Uji koefisien determinasi

Nilai nagelkerke $r$ square menunjukan 0,135 atau $13,5 \%$. Hal tersebut menjelaskan bahwa pada model penelitian ini, variabel leverage, market to book ratio, likuiditas, dan intensitas aset tetap mampu menjelaskan 13,5\% mengenai keputusan revaluasi aset tetap. Sedangkan sisanya dijelaskan oleh variabel lainnya.

4. Pengujian hipotesis

Hasil regresi logistik dapat dilihat pada tabel 4 berikut ini:

Tabel 4. Hasil regresi logistik

\begin{tabular}{|l|l|l|l|l|l|l|l|l|}
\hline & B & S.e & Wald & Df & Sig & Exp & Lower & Upper \\
\hline Lvr & 0.524 & 0.183 & 8.231 & 1 & 0.004 & $\begin{array}{l}1.68 \\
9\end{array}$ & 1.181 & 2.415 \\
\hline Mtb & -0.284 & 0.130 & 4.753 & 1 & 0.029 & $\begin{array}{l}0.75 \\
3\end{array}$ & 0.584 & 0.972 \\
\hline Ldt & 0.076 & 0.072 & 1.136 & 1 & 0.287 & $\begin{array}{l}1.07 \\
9\end{array}$ & 0.938 & 1.242 \\
\hline Iat & 0.384 & 0.244 & 2.479 & 1 & 0.115 & $\begin{array}{l}1.46 \\
8\end{array}$ & 0.910 & 2.367 \\
\hline Cons & -1.230 & 0.316 & $\begin{array}{l}15.16 \\
2\end{array}$ & 1 & 0.000 & $\begin{array}{l}0.29 \\
2\end{array}$ & & \\
\hline
\end{tabular}

Berdasarkan tabel 4 maka diperoleh model persamaan regresi pada penelitian ini sebagai berikut:

$$
\begin{aligned}
\frac{P(R A T)}{1-P(R A T)}=- & 1,230+0,524 L V R-0,284 M T B \\
& +0,076 L T D+0,284 I A T+\varepsilon
\end{aligned}
$$

Berdasarkan persamaan diatas dapat dijelaskan sebagai berikut:

1. Leverage memiliki nilai signifikansi sebesar 0,04 dengan koefisien regresi sebesar 0,524. Hal ini menjelaskan bahwa variabel leverage memiliki pengaruh positif terhadap keputusan revaluasi aset tetap. Dari penjelasan tersebut, maka h1 mengenai leverage memiliki pengaruh positif terhadap keputusan revaluasi aset tetap, diterima.

2. Market to book ratio memiliki nilai signifikansi sebesar 0,029 dengan koefisien regresi sebesar 0,284 . Hal ini menjelaskan bahwa variabel market to book ratio memiliki pengaruh signifikan terhadap keputusan revaluasi aset tetap. Pengaruh tersebet berupa pengaruh negatif terhadap keputusan revaluasi aset tetap. Dari penjelasan tersebut, maka h2 mengenai market to book ratio memiliki pengaruh negatif terhadap keputusan revaluasi aset tetap, diterima.

3. Likuiditas memiliki nilai signifikansi sebesar 0,287 dengan koefisien regresi sebesar 0,076. Nilai tersebut menjelaskan bahwa likuiditas tidak memiliki pengaruh signifikan terhadap keputusan revaluasi aset tetap. Dari penjelasan tersebut, maka h3 mengenai likuiditas memiliki pengaruh positif terhadap keputusan revaluasi aset tetap, ditolak.

4. Intensitas aset tetap memiliki nilai signifikansi sebesar 0,115 dengan koefisien regresi sebesar 0,384 . Nilai tersebut menjelaskan bahwa intensitas aset tetap tidak memiliki pengaruh signifikan terhadap keputusan revaluasi aset tetap. Dari penjelasan tersebut, maka h4 mengenai intensitas aset tetap memiliki pengaruh positif terhadap keputusan revaluasi aset tetap, ditolak.

\section{Pembahasan}

Berdasarkan hasil analisis dari hasil pengujian dalam penelitian ini maka dapat diuraikan bahwa leverage terbukti memiliki pengaruh signifikan terhadap keputusan revaluasi aset tetap sehingga h1 yang menyatakan bahwa leverage memiliki pengaruh positif terhadap keputusan revaluasi aset tetap diterima. Hasil penelitian ini sejalan dengan hasil penelitian yang dilakukan oleh Manihuruk dan Farahmita (2015). Hasil pada penelitian Manihuruk dan Farahmita (2015) menemukan bahwa leverage memiliki pengaruh positif terhadap keputusan revaluasi aset tetap. Hal tersebut didasari bahwa perusahaan dengan tingkat hutang yang tinggi cenderung melakukan revaluasi aset tetap untuk menunjukan bahwa perusahaan masih mampu untuk menangani resiko yang ada. Namun hasil penelitian ini tidak sejalan dengan penelitian yang dilakukan oleh Sherlita dan Sari (2015). Pada 
penelitian Sherlita dan Sari (2015) tidak ditemukan adanya pengaruh yang signifikan antara leverage terhadap keputusan revaluasi aset tetap. Hal tersebut didasari karena adanya informasi yang diwajibkan untuk dipublikasikan mengenai revaluasi aset tetap pada laporan keuangan perusahaan. Kreditur memiliki kecenderungan untuk memperhitungkan dan mempertimbangkan informasi mengenai revaluasi aset tersebut. Selanjutnya, penelitian yang dilakukan oleh Seng dan Su (2010). Pada penelitian Seng dan Su (2010), tidak ditemukan adanya pengaruh signifikan antara leverage dengan keputusan revaluasi aset. Pada penelitian Seng dan Su (2010) dijelaskan bahwa penggunaan revaluasi aset dengan tujuan untuk menyesuaikan kontrak akan menyebabkan timbulnya biaya lebih dimasa mendatang bagi perusahaan dan menurunnya kredibilitas manajemen perusahaan.

Market to book ratio terbukti memiliki pengaruh signifikan terhadap keputusan revaluasi aset tetap. Hal tersebut menyebabkan $\mathrm{H} 2$ mengenai market to book ratio memiliki pengaruh negatif terhadap keputusan revaluasi aset tetap diterima. Argumen atas hasil penelitian ini adalah market to book ratio yang rendah akan mendorong manajemen untuk melakukan revaluasi aset tetap. Hal ini dikarenakan nilai pasar perusahaan yang rendah akan mendorong manajemen untuk meningkatkan nilai tercatat atas suatu perusahaan dengan harapan dapat meningkatkan kepercayaan investor kepada perusahaan. Namun hasil penelitian ini berbeda dengan hasil penelitian yang dilakukan oleh Latifa dan Haridhi (2016). Hasil penelitian yang dilakukan oleh Latifa dan Haridhi (2016) menunjukan bahwa market to book ratio memiliki pengaruh positif terhadap keputusan revaluasi aset tetap.

Likuiditas tidak terbukti memiliki pengaruh signifikan terhadap keputusan revaluasi aset tetap. Hal tersebut menyebabkan h3 mengenai likuiditas memiliki pengaruh positif terhadap keputusan revaluasi aset tetap ditolak. Hasil penelitian yang dilakukan oleh Latifa dan Haridhi (2016) menunjukan bahwa tidak ditemukan adanya pengaruh signifikan antara likuiditas terhadap keputusan revaluasi aset tetap. Hal tersebut didasari adanya asimetri informasi mengenai penialian dari proses revaluasi aset tetap yang nantinya akan memberikan gambaran kepada kreditor mengenai nilai yang dapat diperoleh oleh kreditor dari penjualan aset tetap perusahaan. Hasil penelitian ini juga sejalan dengan penelitian yang dilakukan oleh Andison (2015) bahwa tidak adanya pengaruh signifikan antara likuiditas terhadap keputusan revaluasi aset tetap.

Intensitas aset tetap terbukti tidak memiliki pengaruh signifikan terhadap keputusan revaluasi aset tetap. Hal tersebut menyebabkan h4 mengenai intensitas aset tetap memiliki pengaruh positif terhadap keputusan aset tetap ditolak. Hasil penelitian ini sejalan dengan penelitian yang dilakukan oleh seng dan su (2010). Seng dan su (2010) menjelaskan bahwa tidak adanya pengaruh yang signifikan antara intensitas aset tetap terhadap keputusan revaluasi aset tetap. Hasil penelitian yang dilakukan oleh latifa dan haridhi (2016) menunjukan adanya pengaruh yang positif antara intensitas aset tetap terhadap keputusan revaluasi aset tetap. Revaluasi aset tetap digunakan untuk meningkat nilai dari aset perusahaan dengan harapan dapat meningkatkan kepercayaan investor dan kreditor atas kemampuan perusahaan

\section{SIMPULAN}

Temuan penelitian ini adalah leverage memiliki pengaruh terhadap keputusan revaluasi aset tetap perusahaan. Hal tersebut menunjukan bahwa kepentingan investor mengenai struktur pendanaan menjadi dasar bagi manajemen untuk melakukan revaluasi aset tetap perusahaan untuk meningkatkan kredibilitas mereka di hadapan investor. Kepentingan investor merupakan tanggung jawab yang harus dipenuhi oleh pihak manajemen perusahaan. Kepentingan investor dapat mempengaruhi secara tidak langsung keputusan yang akan diambil oleh investor maupun manajemen perusahaan.

Likuiditas tidak memiliki pengaruh terhadap keputusan revaluasi aset tetap perusahaan. Perubahan aset tetap menjadi aset lancar perusahaan membutuhkan waktu yang lama hal inilah yang menjadi pertimbangan investor dan kreditor terkait dengan likuiditas perusahaan yang didukung dari proses revaluasi. Keputusan revaluasi aset tetap tidak lagi dapat digunakan untuk meningkatkan kredibiltas perusahaan. Hal ini dikarenakan pengungkapan keputusan revaluasi wajib diuraikan dalam laporan keuangan perusahaan. Informasi yang diungkapkan tersebut dapat mempengaruhi secara tidak langsung keputusan manajemen untuk mengabaikan penggunaan revaluasi terkait dengan kredibilitasnya dihadapan investor maupun kreditor perusahaan.

Intensitas aset tetap perusahaan sebagai variabel independen dinyatakan tidak memiliki pengaruh terhadap keputusan revaluasi aset tetap dalam penelitian ini. Tingkat kepadatan aset tetap suatu perusahaan tidak menjadi alasan bagi manajemen 
untuk melakukan revaluasi aset tetap perusahaan. Adanya kewajiban untuk mengungkapkan keputusan revaluasi menjadi dasar argumen dari hasil penelitian ini. Meskipun perusahaan menggunakan revaluasi untuk meningkatkan kepadatan aset tetap mereka, pihak investor maupun kreditor tetap dapat mempertimbangkan keputusan mereka tanpa adanya bias informasi mengenai revaluasi dikarenakan nilai dan informasi yang tertera atas revaluasi dapat diperoleh secara tepat.

Market to book ratio memiliki pengaruh negatif terhadap keputusan revaluasi aset tetap perusahaan. Semakin rendah ekspetasi investor mengenai nilai suatu perusahaan maka semakin tinggi kemungkinan bagi perusahaan untuk melakukan revaluasi aset. Hal ini dikarenakan ketika ekpetasi dari investor rendah, perusahaan akan berusaha untuk memberikan gambaran kepada pihak eskternal mengenai kemampuan yang perusahaan miliki. Perusahaan mengharapkan dengan adanya gambaran yang diberikan dapat membantu perusahaan untuk meningkatkan ketertarikan investor untuk menanamkan sahamnya di perusahaan.

Keterbatasan yang ada dalam penelitian ini adalah nilai dari uji koefisien determinasi dalam penelitian ini adalah sebesar 13,5\% sehingga diduga masih ada variabel-variabel lain yang dapat mempengaruhi keputusan revaluasi aset tetap perusahaan. Beberapa hal yang mungkin perlu dipertimbangkan pada penelitian selanjutnya adalah: sampel perusahaan mungkin dapat diperluas lagi menjadi beberapa sektor industri, dapat menggunakan variabel lainnya seperti bonus issue ataupun dampak terhadap penggunaan revaluasi aset tetap.

\section{REFERENCES}

Army, J., (2013), Pengaruh Leverage, Likuiditas, dan Profitabilitas Terhadap Risiko Sistematis Pada Perusahaan Perbankan Yang Terdaftar di BEI, Skripsi, Universitas Negeri Padang.

Andison., (2015), Fixed Asset Revaluation: Market Reactions, Jakarta: Universitas Trisakti.

Brown, P., Izanand, H. Y. dan Loh., A. L., (1992), Fixed Asset Revaluations and Managerial Incentives. ABACUS, Vol 28 No 1.

Ghozali, I., (2016), Aplikasi Analisis Multivariete IBM SPSS 23, Semarang: Universitas Diponegoro.

Ikatan Akuntansi Indonesia, (2016), Pernyataan Standar Akuntansi Keuangan. Jakarta. Ikatan Akuntan Indonesia.

International Accounting Standard Board, (2003),
IAS 16 Property, Plant, and Equipment.

Latifa, C. A., dan Haridhi, M., (2016), Pengaruh Negosiasi Debt Contract, Political Cost, Fixed Asset Intensity, dan Market to Book Ratio Terhadap Perusahaan Melakukan Revaluasi ASet Tetap (Studi pada Perusahaan Manufaktur yang Terdaftar di Bursa Efek Indonesia Tahun 2010-2014), Jurnal Ilmiah Mahasiswa Ekonomi Akuntansi, Vol 1 No 2, page 166-176.

Manihuruk, T. N. H dan Farahmita, A., (2015), Analisis Faktor-faktor Yang Mempengaruhi Pemilihan Metode Revaluasi Aset Tetap Pada Perusahaan Yang Terdaftar di Bursa Saham Beberapa Negara Asean, Jakarta: Universitas Indonesia.

Missonier-Piera, F., (2007) Motives for Fixed Asset Revaluation: An Empirical Analysis with Swiss Data. Cergy-Pontoise, ESSEC - Business School.

Seng, D. dan Su, J., (2010), Managerial Incentives Behind Fixed Asset Revaluation, International Journal of Business Research, Vol 10 No 2.

Sherlita, E. dan Sari, D., (2015), Pengaruh Negosiasi Debt Contracts Terhadap Perusahaan untuk Melakukan Revaluasi Aset Tetap dan Implikasinya Terhadap Biaya Pajak Penghasilan, Skripsi, Universitas Kristen Satya Wacana Salatiga.

Tay, I., (2009) Fixed Asset Revaluation: Management Incentives and Market Reactions, New Zealand: Lincoln University. 